\title{
Height Estimation using Arm Span as a Proxy among Ghanaians
}

\section{JoshuaTetteh ${ }^{1}$, Nancy Darkoa Darko ${ }^{2}$, Chrissie Stansie Abaidoo *3, Thomas Diby ${ }^{4}$.}

${ }^{1}$ Department of Anatomy, School of Medicine and Dentistry, Kwame Nkrumah University of Science and Technology, Kumasi, Ghana.

${ }^{2}$ Department of Anatomy, School of Medicine and Dentistry, Kwame Nkrumah University of Science and Technology, Kumasi, Ghana.

*3 Department of Anatomy, School of Medicine and Dentistry, Kwame Nkrumah University of Science and Technology, Kumasi, Ghana.

${ }^{4}$ Department of Anatomy, School of Medicine and Dentistry, Kwame Nkrumah University of Science and Technology, Kumasi, Ghana.

\section{ABSTRACT}

\begin{abstract}
Height is an important anthropometric tool and most popular characteristic parameter employed in human identification. However, body height cannot always be ascertained by direct measurement due to various deformities of the extremities in patients with injuries. There is accumulating evidence to demonstrate the use of arm span measurements in the estimation of height but there is very little information on the use of arm span measurements in Ghana. Therefore, this study sought to determine the relationship between height, arm span and sex as well as the correlational efficiency of using arm span as a surrogate for height. This crosssectional study recruited 716 participants [328 males and 388 females] aged 18 to 30 years. Ethical approval and informed participant consent were sought. Male participants were taller and had wider arm span than the females with a statistically significant value [ $<0.001]$. The results also showed that, the mean arm span measurement was higher than the mean height measurement with values of males [arm span: $180.57 \mathrm{~cm}$; height: $170.79 \mathrm{~cm}$ ] and females [arm span: $168.60 \mathrm{~cm}$; height: $161.19 \mathrm{~cm}$ ]. There was a statistically significant strong positive correlation $[p<0.001]$ between the arm span and height in the male, female and pooled sample with " $r$ " values of $0.815,0.788$ and 0.873 respectively. Sex-specific equations to predict height from arm span measurements among Ghanaians were established. This study has developed sex specific equations to predict height from arm span measurements and has proved that arm span can effectively predict height using regression equations.

KEY WORDS: Height, Arm Span, Ghana, Identification, Forensic, Anthropometry.
\end{abstract}

Corresponding Author: Chrissie Stansie Abaidoo, Department of Anatomy, School of Medicine and Dentistry, Kwame Nkrumah University of Science and Technology, Kumasi, Ghana, Tel: +233 208126 817, email: knustsmsanat1@gmail.com

\begin{tabular}{|c|c|c|c|}
\hline Access this Article online & \multicolumn{3}{|c|}{ Journal Information } \\
\hline \multirow[t]{3}{*}{ Quick Response code } & \multicolumn{3}{|c|}{$\begin{array}{l}\text { International Journal of Anatomy and Research } \\
\text { ISSN (E) 2321-4287 | ISSN (P) 2321-8967 } \\
\text { https://www.ijmhr.org/ijar.htm } \\
\text { DOI-Prefix: https://dx.doi.org/10.16965/ijar }\end{array}$} \\
\hline & \multicolumn{3}{|c|}{ Article Information } \\
\hline & $\begin{array}{l}\text { Received: } 01 \text { Mar } 2021 \\
\text { Peer Review: } 02 \text { Mar } 2021 \\
\text { Revised: None }\end{array}$ & $\begin{array}{l}\text { Accepted: } 17 \text { Apr } 2( \\
\text { Published (O): } 05 \mathrm{~N} \\
\text { Published (P): } 05 \mathrm{Ju}\end{array}$ & $\begin{array}{l}1 \\
\text { y } 2021 \\
2021\end{array}$ \\
\hline
\end{tabular}

\section{INTRODUCTION}

Height is an important parameter for the assessment of the growth of an individual and is documented to vary from one population to the other $[1,2]$. The dimensional relationship between body parts and the whole body has been the focus of anatomists, anthropologists and forensic scientists for many years [3]. Height can be accurately determined when the skeletal maturity of an individual is fully attained and without any skeletal deformity. However, in some cases, measurement of 
height is difficult or impossible because of deformities of the trunk or legs, fractures, lower limb amputation or contractures in patients who are unable to stand [3]. In such circumstances, an estimate of body height has to be derived from other reliable anthropometric indicators such as forearm length [4], hand and foot lengths [5-7], arm span [2,8-14], knee height [15-17], sternal height [18-20], length of vertebral column [18,21,22], sitting height [23-25], scapula length [26-28], cranium $[29,30]$ and facial measurements [5,31,32].

Estimation of stature plays an important role in the identification of individuals [33]. Furthermore, it is useful in situations where only mutilated and fragmentary remains are available for examination due to mass disasters both natural and man-made such as earth quakes, tsunamis, hurricanes, flood, terror attacks, bomb blast, mass accidents, explosions, railway accidents, wars and plane crushes [3]. Arm span has been used as a surrogate for height, but not feasible in people with shoulder or arm contractures [11]. The associations of arm span and body height however do vary in different ethnic and racial groups [34]. In anthropometry, arm span is the most reliable parameter for the prediction of the height of individuals [12]. Several studies used arm span measurements in the estimation of height but there is very little information on the use of arm span measurements in Ghana. Therefore, the objective of this study was to determine the relationship between height, arm span and sex as well as the correlational efficiency of using arm span as a substitute for height among Ghanaians.

\section{METHODS}

This cross-sectional study recruited 716 Ghanaian participants, 328 males and 388 females using the simple random sampling method at the Department of Anatomy, School of Medicine and Dentistry, Kwame Nkrumah University of Science and Technology, Kumasi, Ghana. The average age of the participants was $19.24 \pm 1.64$ years with a range of $18-30$ years. Informed Participant consent was sought. Ethical approval was given by the Committee on Human Research, Publication and Ethics of the School of Medical Sciences, Kwame Nkrumah University of Science and Technology and the Komfo Anokye Teaching Hospital with reference number: CHRPE/AP/129/20. Participants with any skeletal deformity of the upper and lower limbs, amputees and non-Ghanaians were excluded from the study. The data collection was done from September 2018 to March 2020.

Data Collection: The sex and age of the participants were determined as recorded on the consent form. The anthropometric parameters, including body height and arm span were taken according to the protocol of the Handbook of physical measurements [35].

Data quality control: Data was collected by two anatomists with knowledge in anatomical positioning and anatomical landmarks in order to achieve the required data quality. Non-significant values for both inter and intra-observer errors were obtained following a preliminary study to ascertain the reliability of the data.

Data Analysis: The analysis was carried out using Statistical Package for Social Sciences [SPSS] version 23.0. The data was normally distributed. Means and standard deviations [SD] were obtained for both anthropometric variables. A comparison of means of body height and arm span with respect to sex was carried out using t-test. The relationship between body height and arm span was established using Pearson's correlation coefficients. Linear regression analyses were performed to examine the extent to which arm span can reliably predict body height. Statistical significance was set at $p<0.05[95$ $\%$ confidence level].

\section{RESULTS}

The mean arm span for the male participants was $180.57 \pm 8.22 \mathrm{~cm}$ with a range of $160.20-200.40 \mathrm{~cm}$ whereas the mean height was $170.79 \pm 7.87 \mathrm{~cm}$ with a range of $151.55-188.80 \mathrm{~cm}$. The mean arm span for the female participants was $168.60 \pm 7.81 \mathrm{~cm}$ [144.75 $-191.60 \mathrm{~cm}$ ] whereas the mean height was $161.19 \pm 6.05 \mathrm{~cm}$ [140.00 - $180.10 \mathrm{~cm}]$. The mean arm span for the pooled population was $174.08 \pm 9.98 \mathrm{~cm}$ with a range of 
$144.75-200.40 \mathrm{~cm}$ whereas the mean height was $165.59 \pm 7.87 \mathrm{~cm}$ with a range of $140.00-188.80 \mathrm{~cm}$.

The mean arm span for the male participants was $9.78 \pm 4.77 \mathrm{~cm}$ more than the body height and was statistically significant $[t=37.130$; $p<0.001$ ], for the female participants, the mean arm span was $7.40 \pm 4.81 \mathrm{~cm}$ more than the body height and was also statistically significant $[\mathrm{t}=30.302 ; \mathrm{p}<0.001]$. The pooled mean arm span was $8.49 \pm 4.93 \mathrm{~cm}$ and was also statistically significant $[\mathrm{t}=46.053$; $p<0.001$ ]. Also, the mean height of the male participants was $10.89 \pm 7.80 \mathrm{~cm}$ more than that of the female participants and was statistically significant $[t=25.266, p<0.001]$, whereas the mean arm span of the male participants was $13.58 \pm 9.48 \mathrm{~cm}$ more than that of the female participants and was statistically significant $[t=25.950, p<0.001]$.

Table 1: Correlation between Body Height and Arm Span of the Study Subjects.

\begin{tabular}{cccc}
\hline & $\mathbf{r}$ & $\begin{array}{c}95 \% \text { Confidence } \\
\text { Interval }\end{array}$ & p-value \\
\hline Male & 0.815 & $0.594-0.693$ & $<0.001$ \\
Female & 0.788 & $0.563-0.658$ & $<0.001$ \\
Pooled & 0.873 & $0.661-0.717$ & $<0.001$ \\
\hline
\end{tabular}

$\mathbf{p}=$ probability, statistically significant difference [ $p<0.05$ ], $r=$ Correlation Coefficient

The correlation coefficient between height and arm span was $0.815,0.788$ and 0.873 for males, females and the pooled sample respectively. All the correlation coefficients for the males, females and the pooled sample indicates a significantly strong, positive linear relationship between arm span and height statistically [p < 0.001] [Table 1].

Table 2: Linear Regression Analysis for the Prediction of Height Using Arm Span.

\begin{tabular}{cccccc}
\hline & $\mathbf{R}^{2}$ & Adj. $\mathbf{R}^{2}$ & SEE & $\begin{array}{c}\text { Regression } \\
\text { Equations }\end{array}$ & p-value \\
\hline Male & 0.664 & 0.663 & 3.77 & $\begin{array}{c}54.605+ \\
{\left[0.643^{*} \mathrm{MA}\right]}\end{array}$ & $<0.001$ \\
Female & 0.621 & 0.62 & 3.733 & $\begin{array}{c}58.291+ \\
{[0.610 * \mathrm{FA}]}\end{array}$ & $<0.001$ \\
Pooled & 0.762 & 0.762 & 3.839 & $\begin{array}{c}45.632+ \\
{[0.689 * \mathrm{PA}]}\end{array}$ & $<0.001$ \\
\hline
\end{tabular}

$\mathbf{R}^{2}=$ coefficient of determination, $\mathbf{A d j} . \mathbf{R}^{2}=$ adjusted coefficient of determination,

SEE = Standard Error of Estimate, $\mathbf{M A}=$ male arm span, $\mathrm{FA}=$ Female arm span,

$\mathrm{PA}=$ pooled arm span, $\mathbf{p}=$ probability, statistically significant level $[p<0.05]$
Table 2 shows the results of linear regression of the anthropometric parameters. The results show that, arm span can significantly predict height of the Ghanaian population [ $<0.001$, with an adjusted coefficient of determination of $66.3 \%, 62 \%$ and $76.2 \%$ for the males, females and the pooled respectively. The Table also shows regression equations for stature estimation using the arm span measurements obtained in the study. In males, Height $=60.695+\left[0.609^{*} \mathrm{MA}\right]$. In females, Height $=63.525+[0.580 * \mathrm{FA}]$ and in the pooled, Height $=49.536+\left[0.667^{*} \mathrm{PA}\right]$. The regression equation for the pooled data gave the best prediction value.

Table 3: Paired Sample t-test between actual and predicted height of participants.

\begin{tabular}{ccccccccc}
\hline Sex & AMH \pm SD $[\mathrm{cm}]$ & $\begin{array}{c}\mathrm{PMH} \pm \text { SD } \\
{[\mathrm{cm}]}\end{array}$ & MD & SED & $\begin{array}{c}95 \% \mathrm{Cl} \\
\text { Lower }\end{array}$ & Upper & T & p-value \\
\hline Male & $170.79 \pm 6.49$ & $170.71 \pm 5.28$ & 0.08 & 0.208 & -0.329 & 0.488 & 0.383 & 0.702 \\
\hline Female & $161.23 \pm 6.13$ & $161.18 \pm 5.11$ & 0.06 & 0.189 & -0.314 & 0.43 & 0.306 & 0.76 \\
\hline Pooled & $165.59 \pm 7.87$ & $165.57 \pm 6.87$ & 0.02 & 0.143 & -0.266 & 0.297 & 0.109 & 0.914 \\
\hline
\end{tabular}

$\mathbf{c m}=$ centimeter, $\mathbf{S D}=$ Standard Deviation, $\mathbf{T}=\mathrm{t}$-statistic; $\mathbf{p}=$ probability, statistically significance level,

$\mathbf{A M H}=$ Actual Mean Height, $\mathbf{P M H}=$ Predicted Mean Height, $\mathbf{M D}=$ Mean Difference,

SED = Standard Error of Difference, $\mathbf{C l}=$ Confidence Interval

Paired Samples t-test was conducted to evaluate the existence of mean difference between the actual and predicted height of the participants. The highest mean difference was recorded for the males followed by the females and then the pooled sample. However, these differences were not statistically significant as shown in Table 3 above.

\section{DISCUSSION}

Anthropometry is the external description and measurement of the human body parts for comparison purposes and establishing norms for sexual dimorphism, age and race [36]. The prediction of height using arm span measurement has been attempted by many authors [13,34,37-39]. This study has provided an update on average body heights among Ghanaian males and females.

Height Measurement: Height is a significant parameter for the assessment of growth and development of an individual. Height varies from one population to another and also with 
age [1]. In the present study, male participants were taller than the females with statistically significant sex difference [ $p<0.001$ ]. A similar study conducted by Kasunka et al. [2015] in Dakshina Kannada district India revealed that, adult males were taller than adult females with a mean height of $167.93 \pm 6.98 \mathrm{~cm}$ and $157.38 \pm 6.96 \mathrm{~cm}$ respectively [ $<<0.001]$. Venkataraman et al. [2015] reported the pooled mean height of an Indian population to be $162.75 \pm 9.26 \mathrm{~cm}$ [40]. A person's height could be influenced by indicators such as rate of growth, body size, physiological variables, physical capacities and nutritional status of the human body [41,42]. Despite all these factors, the similarities in the present study and the other studies may be due to the fact that, the duration of pubertal growth is longer in boys than in girls resulting in the ossification of bones ceasing earlier in females than in males contributing to an appreciable increase in height of males than females [43-45].

Arms Span Measurements: In the determination of arm span from the present study, the male group had a wider arm span compared to that of the females. A statistically significant difference between male and female arm span was established $[p<0.001]$. Results from the present study was in agreement with that by Kasunka et al. [2015], which included 153 participants [ $20-25$ years] and recorded the mean arm span for females as $161.63 \mathrm{~cm}$ and $176.2 \mathrm{~cm}$ for males. In a similar study by Venkataraman et al. [2015] the mean arm span was $169.83 \pm 8.17 \mathrm{~cm}$. Observations made from both the present and similar studies show that, males have a greater arm span than females. Biologically males have larger, more robust skeletal elements and greater muscle mass than females.

Comparison of Height and Arm Span Measurements: The results of this study showed that, the mean arm span measurement was higher than the mean height measurement among Ghanaians with values of males [arm span: $180.57 \mathrm{~cm}$; height: $170.79 \mathrm{~cm}$ ] and females [arm span: $168.60 \mathrm{~cm}$; height: $161.19 \mathrm{~cm}$ ] which are similar but lower in comparison to the mean arm span and height in a research conducted among the Urhobos in the Delta
State of Nigeria which showed that, male arm span and height were $184.56 \pm 9.54 \mathrm{~cm}$ and $173.0 \pm 7.7 \mathrm{~cm}$ while females had arm span and height measurements of $173.61 \pm 9.07 \mathrm{~cm}$ and $164.6 \pm 7.0 \mathrm{~cm}$ respectively [38]. Another study with higher values than the present study was conducted among Nigerian adults of the Bekwara ethnic group of Cross River State by Esomonu et al. [2015] where mean arm span was found to be $184.57 \mathrm{~cm}$ in males and $172.77 \mathrm{~cm}$ in females and height of males and females to be $169.73 \mathrm{~cm}$ and $163.00 \mathrm{~cm}$ respectively [34]. However, the height of the Ghanaian male was only numerically higher than the Bekwara ethnic group study and not statistically significant. On the other hand, the values of the present study were higher than the values in another study by Ter Goon et al. [2011] in Benue State University who found male arm span of $173.20 \pm 9.10 \mathrm{~cm}$ and height of $167.40 \pm 6.60 \mathrm{~cm}$ with female arm span of $164.20 \pm 95.90 \mathrm{~cm}$ and height of $160.20 \pm 95.20$ $\mathrm{cm}$ in Nigerian adults. A study in India by Singh et al. [2012] found the average arm span in Northern Indian males and females to be $166.4 \mathrm{~cm}$ and $157.44 \mathrm{~cm}$ respectively and height to be $165.96 \mathrm{~cm}$ in males and $156.4 \mathrm{~cm}$ in females which are also lower as compared to the values of this study [46]. Arifi et al. [2017] in a study conducted on adolescents aged between 18-20 years in Kosovo found that, male arm span was $180.91 \pm 6.92 \mathrm{~cm}$ with height of $178.60 \pm 5.73 \mathrm{~cm}$ while females recorded $165.60 \pm 6.03 \mathrm{~cm}$ and $165.33 \pm 4.45$ $\mathrm{cm}$ for arm span and height respectively. Popovic et al. [2016] in a study among Macedonian adults, recorded male and female arm span values of $178.78 \pm 7.71 \mathrm{~cm}$ and $164.41 \pm 6.42 \mathrm{~cm}$ and heights of $178.10 \pm 6.79$ $\mathrm{cm}$ and $164.58 \pm 5.40 \mathrm{~cm}$ for males and females respectively [47]. On the other hand, a study conducted in a Kosovan population showed that, the average Kosovan male arm span and height were recorded as $181.20 \pm 7.02 \mathrm{~cm}$ and $179.52 \pm 5.96 \mathrm{~cm}$ respectively and the average female arm span and height were $165.60 \pm 5.87$ $\mathrm{cm}$ and $165.72 \pm 4.93 \mathrm{~cm}$ respectively [37].

This places Kosovans among the tallest nations in Europe and to a larger extent, the world. The difference in height between the present 
study and that reported by other researchers can be explained by the different environmental factors, different genetic constitution and nutrition across populations which play important roles in human growth and development [48].

The use of various anthropometric indicators for the prediction of stature is very evident from the past decades and it has been analyzed by many researchers. Nonetheless, it is important to note that, arm span has been found to be the most reliable body measurement for prognosticating the height of an individual $[2,13,37]$. The relationship between stature and arm span has been assessed among Europeans [3] and in Africans [49]. It has been reported that, equations for estimating height varies from race to race as well as ethnic group to ethnic group [37].

Estimation of Height from Arm Span Measurement: There was a statistically significant strong relationship [ $p<0.001]$ between the arm span and height in the male, female and pooled populations with correlation coefficient values of $0.815,0.788$ and 0.873 respectively. This is in strong agreement with studies of other research works in different populations where strong associations were found between arm span and height with values of $r=0.891$ for women; $r=0.840$ for men [50], $r=0.989$ [pooled] [51], $r=0.806$ for women; $r$ $=0.756$ for men [52] and $r=0.933$ [pooled] [53]. The correlation coefficient of this study on the other hand is higher than that observed in some other studies; [38] with " $r$ " values of 0.509: male; 0.498: female in Nigeria, [13] with " $r$ " value in percentages for males being 67.626 and 55.156 for females with a combined " $r$ " value of 0.83 also in Nigeria. In a study conducted by Arifi et al. [2017] in a Kosovan population, it was recorded that, correlation coefficient between arm span and height for males and females was 0.794 and 0.766 respectively.

The linear regression equation derived for the prediction of male height in this study group was $54.605+[0.643 \times$ Arm span], while that of females was $58.291+[0.610 \times$ Arm span $]$ and that of the pooled population being $45.632+$ [0.689 $\times$ Arm span] with an adjusted $R^{2}$ of
$66.3 \%, 62 \%$, and $76.2 \%$ respectively. The models from this study indicates that $66.3 \%$, $62 \%$ and $76.2 \%$ of the total variation in height is significantly accounted for by the change in arm span within the range of values of arm span for the Ghanaian males, females and the pooled sample respectively. These equations derived in this study were totally different from that of other studies. The regression equations for the males and females of the Benue State indigenes of Nigeria which were [stature = $67.63+0.577$ [arm span]; $r=0.77$ ] and [stature $=55.16+0.642$ [arm span]; $r=0.72$ ] respectively has a slightly higher coefficient of determination than that in the present study. These differences could be attributed to the different population or sample characteristics. In Malawian children, height of boys and girls were predicted as $17.043+[0.348 \times$ age] $+[0.815 \times$ arm span $]$ and $18.158+[0.265 \times$ age] $+[0.817 \times$ arm span] respectively [54]. Yet, in another research conducted among the Bekwara ethnic group in Cross River State of Nigeria, the equation derived for the males and females were $25.71+[0.781 \times$ arm span] with a recorded mean predicted height value of $158.2 \mathrm{~cm}$ for males and $31.83+[0.753 \times$ arm span] with height prediction value of $154.0 \mathrm{~cm}$ for females [34]. Among Medical Students of Maharashtra in India, the equation for the estimation of height from arm span in males was $31.25+[0.80 \times$ arm span] and in females, it was $33.54+[0.77 \times$ arm span] [3]. The Paired Samples t-test conducted in this study to evaluate the existence of mean differences between the actual and predicted height of participants showed no statistically significant differences with values of $p=0.702, p=0.760$ and $p=0.914$ for male, female and pooled populations respectively. These values clearly show that, the regression equations derived in this study can be used to effectively predict the height of Ghanaian individuals in situations such as bed ridden patients or in accident cases where the standing height is impossible or difficult to measure.

\section{CONCLUSION}

In this study, males were significantly taller than females. Arm span measurements were greater in males than in females and were 
statistically significant. The study showed a strong positive correlation between height and arm span in both males and females. This study has also developed sex specific equations to predict height from arm span measurements among Ghanaians with the pooled equation being the best predictor followed by the male-specific equation and then the female-specific equation. These equations are only applicable within the stated range of the arm span measurements of the Ghanaian population since these equations are population-specific. The study has also provided data for forensic anthropologists and health workers to help in drug administration when patient actual height cannot be easily measured and it is a significant identification parameter which can be used in medico-legal cases.

Funding: No funding was received for this work.

\section{REFERENCES}

[1]. Kasunka K, Raj JO, Arulsingh W. Correlation between Standing Height and Arm Span in Young Adults-A Cross Sectional Study. Appl Res J. 2015;1[4]:242-6.

[2]. Bjelica D, Popoviæ S, Kezunoviæ M, Petkoviæ J, Jurak G, Grasgruber P. Body height and its estimation utilising arm span measurements in Montenegrin adults. Anthropol Notebooks. 2012;18[2].

[3]. Supare MS, Bagul AS, Pandit S V, Jadhav JS. Estimation of stature from arm span in medical students of Maharashtra, India. Ann Med Health Sci Res. 2015;5[3]:218-21.

[4]. Ilayperuma I, Nanayakkara G, Palahepitiya N. A model for the estimation of personal stature from the length of forearm. Int J Morphol. 2010;28[4]:1081-6.

[5]. Agnihotri AK, Agnihotri S, Jeebun N, Googoolye K. Prediction of stature using hand dimensions. J Forensic Leg Med. 2008;15[8]:479-82.

[6]. Kanchan T, Menezes RG, Moudgil R, Kaur R, Kotian MS, Garg RK. Stature estimation from foot dimensions. Forensic Sci Int. 2008;179[2-3]:241-e1.

[7]. Rastogi P, Nagesh KR, Yoganarasimha K. Estimation of stature from hand dimensions of north and south Indians. Leg Med. 2008;10[4]:185-9.

[8]. Bubanja M, Vujovic D, Tanase GD, Hadzic R, Milasinovic R. Body Height and Its Estimation Utilizing Arm Span Measurements in Female Adolescents from Central Region in Montenegro. Sport Mont. 2015;12[4345]:277-82.

[9]. Masanovic B. Standing height and its estimation utilizing arm spam and foot length measurements in dinaric alps population: a systematic review. Sport Mont. 2018;16[2]:101-6.
[10]. Popoviæ S. Arm-span measurement as an alternative estimation of true height in Montenegrin young adults of both sexes: A national survey. Anthropol Notebooks. 2018;24[1].

[11]. Forman MR, Zhu Y, Hernandez LM, Himes JH, Dong Y, Danish RK, et al. Arm span and ulnar length are reliable and accurate estimates of recumbent length and height in a multiethnic population of infants and children under 6 years of age. J Nutr. 2014;144[9]:1480-7.

[12]. Sah RP, Kumar A, Bhaskar RK. Body height and its estimation utilizing arm span measurements in population of Birgunj area of Nepal: an anthropometric study. J Coll Med Sci. 2013;9[4]:9-14.

[13]. Ter Goon D, Toriola AL, Musa DI, Akusu S. The relationship between arm span and stature in Nigerian adults. Kinesiology. 2011;43[1].

[14]. Akodu SO, Diaku-Akinwumi IN, Kehinde OA, Njokanma OF. Evaluation of arm span and sitting height as proxy for height in children with sickle cell anemia in Lagos, Nigeria. J Am Coll Nutr. 2014;33[6]:437-41.

[15]. Fogal AS, Franceschini S do CC, Priore SE, Cotta RMM, Ribeiro AQ. Stature estimation using the knee height measurement amongst Brazilian elderly. Nutr Hosp. 2015;31[2]:829-34.

[16]. Ozaslan A, Karadayi B, Kolusayin MO, Kaya A, Afsin H. Predictive role of hand and foot dimensions in stature estimation. Rom J Leg Med. 2012;20[1]:41-6.

[17]. Maleki S, Shariatpanahi Z. Estimation of Stature in Iranian Adults Using Knee Height. Malays J Nutr. 2017;23[1]

[18]. Macaluso PJ, Lucena J. Stature estimation from radiographic sternum length in a contemporary Spanish population. Int J Legal Med. 2014;128[5]:84551.

[19]. Marinho L, Almeida D, Santos A, Cardoso HF V. Is the length of the sternum reliable for estimating adult stature? A pilot study using fresh sterna and a test of two methods using dry sterna. Forensic Sci Int. 2012;220[13]:292-e1.

[20]. Yonguc GN, Kurtulus A, Bayazit O, Adiguzel E, Unal I, Demir S, et al. Estimation of stature and sex from sternal lengths: an autopsy study. Anat Sci Int. 2015;90[2]:89-96.

[21]. Milani C, Panattoni GL. Estimation of stature from the vertebral column in physical and forensic anthropology. J Biol Res della Soc Ital di Biol Sper. 2013;86[1].

[22]. Zhang K, Luo Y, Fan F, Zheng J, Yang M, Li T, et al. Stature estimation from sternum length using computed tomography-volume rendering technique images of western Chinese. J Forensic Leg Med. 2015;35:40-4.

[23]. Grasgruber P, Prce S, Straèárová N, Hrazdíra E, Cacek J, Popoviæ S, et al. The coast of giants: an anthropometric survey of high schoolers on the Adriatic coast of Croatia. PeerJ. 2019;7:e6598.

[24]. Silveira EA, Ferreira CC da C, Pagotto V, Santos AS e A de $C$, Velasquez Melendez $G$. Total and central obesity in elderly associated with a marker of undernutrition in early life-sitting height to stature ratio: A nutritional paradox. Am J Hum Biol. 2017;29[3]:e22977.

[25]. Gardasevic J. Standing Height/Sitting Height Ration in Eastern-Kosovan Adolescents. Available SSRN 3141566. 2018; 
[26]. Giurazza F, Del Vescovo R, Schena E, Cazzato RL, D’Agostino F, Grasso RF, et al. Stature estimation from scapular measurements by CT scan evaluation in an Italian population. Leg Med. 2013;15[4]:202-8.

[27]. Macaluso PJ, Lucena J, Ansah EO, Abaidoo CSCS, Diby $\mathrm{T}$, Tetteh J, et al. Craniometric analysis for estimation of stature in Nepalese population-A study on an autopsy sample. Forensic Sci Int. 2015;6[1]:187-e1.

[28]. Zhang K, Cui J, Luo Y, Fan F, Yang M, Li X, et al. Estimation of stature and sex from scapular measurements by three-dimensional volume-rendering technique using in Chinese. Leg Med. 2016;21:58-63.

[29]. Torimitsu S, Makino Y, Saitoh H, Sakuma A, Ishii N, Yajima $D$, et al. Stature estimation from skull measurements using multidetector computed tomographic images: a Japanese forensic sample. Leg Med. 2016;18:75-80.

[30]. Shrestha R, Shrestha PK, Wasti H, Kadel T, Kanchan T, Krishan K. Craniometric analysis for estimation of stature in Nepalese population-A study on an autopsy sample. Forensic Sci Int. 2015;248:187-e1.

[31]. Jervas E, Anibeze CIP, Uloneme GC, Anyanwu GE. Stature estimation of the Igbos using cephalo-facial anthropometry. J Forensic Res. 2015;6[4]:1.

[32]. Datta S, Sawant VG. Correlation of stature with facial measurements of Maharashtrian adults. Indian J Basic Appl Med Res. 2017;6:305-11.

[33]. Kuppast N, Kanaki A, Shahina JVB, Iddalgave S, Mugadlimath $A$. Estimation of stature from middle fingers length of population in Davangere district. IJBR. 2014;5[11]:65-7.

[34]. Esomonu UG, ljomone OM, Mba C, Oranusi A. Estimation of stature using arm span length amongst Bekwara ethnic group of Cross River State, Nigeria. Ann Bioanthropology. 2015;3[2]:55.

[35]. Gripp KW, Slavotinek AM, Allanson JE. Handbook of physical measurements. Oxford University Press; 2013.

[36].Udoh Uwemedimo G, Edem Gabriel D, Johnson Ekemini I. Relationship between height and Armspan length in adults of the Annang ethnic group of Nigeria. IJAR. 2017;3[12]:175-9.

[37]. Arifi F, Bjelica D, Sermaxhaj S, Gardasevic J, Kezunovic M, Popovic S. Stature and its Estimation Utilizing Arm Span Measurements in Kosovan Adults: National Survey. Int J Morphol. 2017;35[3].

[38]. Anibor E, Ogbor-Omorie E, Nwagbara A. The use of arm span to estimate height among the Urhobos in Delta state of Nigeria. African J Cell Pathol. 2014;3[10]:16-9.

[39]. Gardasevic J, Rasidagic F, Krivokapic D, Corluka M, Bjelica D. Stature and its estimation utilizing arm span measurements in male adolescents from Federation of Bosnia and Herzegovina Entity in Bosnia and Herzegovina. Montenegrin J Sport Sci Med. 2017;6[1]:37.

[40].Venkataraman R, Ranganathan L, Nirmal V, Kameshwaran J, Sheela CV, Renuka M V, et al. Height measurement in the critically ill patient: $A$ tall order in the critical care unit. Indian J Crit care Med peer-reviewed, Off Publ Indian Soc Crit Care Med. 2015;19[11]:665.
[41]. Datta Banik S. Arm span as a proxy measure for height and estimation of nutritional status: A study among Dhimals of Darjeeling in West Bengal India. Ann Hum Biol. 2011;38[6]:728-35.

[42]. De Lucia E, Lemma F, Tesfaye F, Demisse T, Ismail S. The use of armspan measurement to assess the nutritional status of adults in four Ethiopian ethnic groups. Eur J Clin Nutr. 2002;56[2]:91-5.

[43]. García BC, Gónzalez AV, Frías EG, Arana CC, Díaz EM, Tolmo MD. Assessment of the secular trend in puberty in boys and girls. In: Anales de pediatria [Barcelona, Spain: 2003]. 2010. p. 320-6.

[44]. Wang Q, Wang X, luliano Burns S, Ghasem Zadeh A, Zebaze R, Seeman E. Rapid growth produces transient cortical weakness: a risk factor for metaphyseal fractures during puberty. J Bone Miner Res. 2010;25[7]:1521-6.

[45]. Flinn EB, Strickland BK, Demarais S, Christiansen D. Age and gender affect epiphyseal closure in whitetailed deer. Southeast Nat. 2013;12[2]:297-306.

[46]. Singh A, Kumar A, Chavali KH, Harish D. Use of armspan and foot length for estimation of height of the person. J Punjab Acad Forensic Med Toxicol. 2012;12[2]:87-91.

[47]. Popovic S, Bjelica D, Georgiev G, Krivokapic D, Milasinovic R. Body height and its estimation utilizing arm span measurements in Macedonian adults. Anthropol. 2016;24[3]:737-45.

[48]. Basciftci FA, Uysal T, Buyukerkmen A. Craniofacial structure of Anatolian Turkish adults with normal occlusions and well-balanced faces. Am J Orthod Dentofac Orthop. 2004;125[3]:366-72.

[49]. Khan MA, Khan MA, Khan MA. The Use of Arm Span as a Predictor of Height in Young Adults: A Cross-Sectional Study. Int J Heal Sci Res. 2017;7[8]:115-9.

[50]. Chen W-Y, Lin Y-T, Chen Y, Chen K-C, Kuo BI-T, Tsao $\mathrm{P}-\mathrm{C}$, et al. Reference equations for predicting standing height of children by using arm span or forearm length as an index. J Chinese Med Assoc. 2018;81[7]:649-56.

[51]. Malaviya SK, Saswihali S, Chirag G, Hathi M, Mehta SR. Stature estimation from arm span in living people of Terdal region. Indian J Forensic Community Med. 2019;6[1].

[52]. Pertiwi J, Kartasurya MI, Lukmono DTH, Setyawan H, Martini M. A Calculating Actual Stature of Elderly through Arm Span and Knee Height Measurements. Heal Notions. 2018;2[2]:265-70.

[53]. Salihu H, Koca A, Miftari F, Arifi F. Stature and Its Estimation Utilizing Arm Span Measurements of both gender Adolescents from Ferizaj Region in Kosovo. J Educ Heal Sport. 2018;8[11]:32-43.

[54]. Zverev YP. Short Report Relationship between arm span and stature in Malawian adults. Ann Hum Biol. 2003;30[6]:739-43.

How to cite this article: JoshuaTetteh, Nancy Darkoa Darko, Chrissie Stansie Abaidoo, Thomas Diby. Height Estimation using Arm Span as a Proxy among Ghanaians. Int J Anat Res 2021;9(2.2):79847990. DOI: 10.16965/ijar.2021.120 